\title{
PENGETAHUAN DAN STIGMA PERAWAT TERKAIT ORANG DENGAN HIVIAIDS (ODHA)
}

\author{
Sandy Dwi Aryanto ${ }^{1}$, Ibrahim Rahmat ${ }^{2}$, Anita Kustanti ${ }^{3, *}$ \\ ${ }^{1}$ Mahasiswa Program Studi S1 Ilmu Keperawatan \\ Fakultas Kedokteran Universitas Gadjah Mada, \\ J1. Farmako Sekip Utara, 55281, Yogyakarta, Indonesia \\ ${ }^{2}$ Dosen Departemen Keperawatan Jiwa Program Studi Ilmu Keperawatan \\ Universitas Gadjah Mada, Jl. Farmako Sekip Utara, 55281, Yogyakarta, Indonesia \\ ${ }^{3}$ Dosen Keperawatan Medikal Bedah Program Studi Ilmu Keperawatan \\ Universitas Gadjah Mada, Jl. Farmako Sekip Utara, 55281, Yogyakarta, Indonesia \\ *)E-mail: kustantianita@gmail.com
}

Diterima: Juni 2018, diterbitkan: Agustus 2018

\begin{abstract}
ABSTRAK
Latar Belakang: Stigma merupakan masalah yang dihadapi orang dengan HIV/AIDS (ODHA). Dampak buruk terjadinya stigma adalah sulitnya memut uskan rantai penularan HIV/AIDS. Stigma dapat terjadi dimana saja, salah sat unya didalam pelayanan kesehatan dan pelaku stigma adalah perawat. Perawat merupakan bagian garis depan dalam melakukan perawatan yang seharusnya tidak melakukan sikap negatif seperti stigma. Sikap stigma yang dilakukan oleh perawat disebabkan karena adanya ketakutan dan adanya kesalahan presepsi tetang penularan atau pencegahan HIV/AIDS. Faktor yang menyebabkan hal tersebut dipengaruhi oleh pengetahuan. Tujuan Penelitian: Mengetahui hubungan antara pengetahuan dengan stigma perawat terkait ODHA di salah satu rumah sakit swasta di Yogyakarta. Metode: Penelitian ini merupakan penelitian kuantitatif dengan desain cross sectional. Subjek pada penelitian ini adalah perawat yang bekerja di bangsal yang kemungkinan menangani pasien ODHA di salah satu rumah sakit swasta di Yogyakarta dengan jumlah 63 orang. Data diambil dari bulan Desember 2016-Februari 2017. Instrumen yang digunakan pada penelitian ini dengan kuesioner HIV-KQ-18 untuk mengukur tingkat pengetahuan dan kuesioner SHASS untuk mengukur sikap stigma. Pada kuesioner HIV-KQ-18 dilakukan uji kerterbacaan. Kuesioner SHASS telah dilakukan uji validitas dan uji reliabilitas pada penelitian sebelumnya. Analisis menggunakan uji korelasi Spearman rank. Hasil: Sebanyak 40 (63.5\%) responden mempunyai pengetahuan cukup dan sebanyak 50 (79.4\%) responden mempunyai stigma tinggi. Tidak terdapat hubungan antara pengetahuan dengan stigma perawat terkait ODHA di salah satu RS swasta di Yogyakarta. Kesimpulan: Pengetahuan perawat tentang ODHA masih perlu ditingkatkan. Perlu dilakukan usaha terkait masih tingginya stigma perawat tentang ODHA, misalnya bagi institusi pendidikan dapat menambahkan kurikulum stigma perawat terkait ODHA, melakukan kuliah atau workshop dengan ahli, ODHA, Dinas Kesehatan, dan pelayanan kesehatan, dan pelatihan tentang HIV/AIDS. Kata kunci: ODHA, pengetahuan, stigma perawat
\end{abstract}

\section{KNOWLEDGE WITH NURSE'S STIGMA RELATED PLWHA ABSTRACT}

Background: Stigma is a problem faced by people living with HIVIAIDS (PLWHA). The adverse effect of stigma is difficulty in conducting prevention for HIV/ADIS transmission. Stigma could be occur in everywhere, including health facilities with the actor are nurses. Nurse as a leading care provider should not giving stigma. Stigma produced by nurse are a result of scares and misperception regard HIV/AIDS transmission and prevention. These factors are affected by knowledge. Objective: To understand the correlation between knowledge with nurse's stigma related PLWHA in the one of private hospital in Yogyakarta. Method: This was a quantitative research with cross sectional design. Subject on this research was 
63 nurses whose working in the ward to handle care for PLWHA patients in a one of the private hospital in Yogyakarta. Data collected from December 2016 unitl February 2017. Instruments on this research was HIV-KQ-18 designed to measure the knowledge level and SHASS questionnaire to measure the stigma. The HIV-KQ-18 questionnaire was not tested for validity and reliability testing, only a reading test was conducted. The SHASS questionnaire has been tested for validity and reliability testing by previous researchers. Data analyzed with spearman rank correlation. Result: 40 respondents (63,5\%) have enough knowledge and 50 respondents $(79,4 \%)$ in a high stigma. There was no significant correlation between knowledge with nurse's stigma related PLWHA in a one of the private hospital in Yogyakarta. Conclusion: Nurses knowledge about PLWHA still needs to be improved. Efforts need to be made regarding the high stigma of nurses about PLWHA, for example for educational institutions can add a stigma curriculum for nurses related to PLWHA, conduct lectures or workshops with experts, PLWHA, Health Services, and health services, and training about HIVIAIDS.

Keyword: knowledge, nurses stigma, PLWHA

\section{LATAR BELAKANG}

Jumlah penderita Human Immunodeficiency Virus/Acquired Immuno Deficiency Syndrome (HIV/AIDS) setiap tahun bertambah. Tahun 2000 terdapat 28,6 juta orang hidup dengan HIV dan pada tahun 2015 menjadi 36,7 juta orang hidup dengan HIV di dunia (UNAIDS, 2016). Jumlah penderita HIV di Indonesia dari tahun 1987 sampai September 2014 sebanyak 150.296 orang dan penderita AIDS sebanyak 55.799 orang (Kemekes RI, 2014). Di tahun 2015 jumlah kasus HIV di Indonesia dilaporkan sebanyak 24.791 dan jumlah kasus AIDS 3.127 (Kemenkes RI Ditjen PP dan PL, 2015).

Provinsi Daerah Istimewa Yogyakarta (DIY) berada di peringkat 13 dari 33 provinsi di Indonesia dengan jumlah kasus HIV 2.611 dan kasus AIDS 916. Prevalensi kasus AIDS per 100.000 penduduk Indonesia, DIY menduduki peringkat 8 dengan prevalensi 26,49 (Kemenkes RI Ditjen PP dan PL, 2014). Kasus HIV dan AIDS yang terjadi di DIY dari periode 1993 sampai Maret 2015 berjumlah 3.334 kasus HIV dan 1.314 kasus AIDS dengan prevalensi laki-laki lebih banyak dibandingkan dengan perempuan. Dari 5 Kabupaten di DIY, Kota Yogyakarta untuk jumlah kasus berdasarkan wilayah, orang yang mengalami HIV berjumlah 775 orang dan AIDS berjumlah 231 orang dan diawal tahun 2016 sampai bulan Maret 2016 telah ditemukan 186 kasus HIV dan 64 kasus
AIDS di DIY (Komisi Penanggulangan AIDS Provinsi DIY, 2016).

Stigma merupakan salah satu masalah yang dihadapi oleh orang dengan HIVIAIDS (ODHA). Dampak buruk jika terjadi stigma di masyarakat akan menimbulkan pengucilan, pengusiran, pemutusan hubungan kerja, dan dapat terjadi kekerasan. Selain itu, stigma dapat mempengaruhi psikis, emosi, spiritual, bersosial di masyarakat, akses ke pelayanan kesehatan dan layanan lain (pendidikan) hilang, serta dapat menganggu rasa aman dan nyaman untuk hidup bermasyarakat (Kemenkes RI Ditjen PP dan PL, 2012).

ODHA dapat mendapatkan stigma di dalam keluarga, fasilitas pelayanan kesehatan, lingkungan tempat tinggal, dan lingkungan tempat kerja (Chandra et al., 2013). Salah satu tempat terjadinya stigma adalah pelayanan kesehatan. Padahal setiap fasilitas pelayanan kesehatan dilarang menolak pengobatan dan perawatan terhadap ODHA, terkecuali jika tidak mampu untuk mengobati dan merawat pasien ODHA. Masalah tersebut dapat diatasi dengan melakukan rujukan ke fasilitas pelayanan kesehatan lain. Pelayanan kesehatan yang dimaksud meliputi rumah sakit, puskesmas, dan klinik yang dapat memengaruhi terjadinya stigma dan diskriminasi. Hal tersebut dapat terjadi karena adanya penetapan kebijakan, standar operasional prosedur (SOP), penyedia sarana, fasilitas, bahan, dan alat- 
alat perlindungan diri untuk menangani pasien HIVIAIDS (Kemenkes RI, 2013).

Masalah tersebut dialami oleh ODHA di DIY yang mendapatkan kesulitaan saat melakukan akses terapi antiretroviral (ARV) dan pelayanan medis. Kesulitan tersebut seperti menunggu lama, padahal sudah mendapatkan rujukan dari dokter lain, perawat yang tidak ramah, dan tidak menyenangkan. Sikap tidak menyenangkan ini dapat berupa sikap perawat yang seenaknya, melemparkan tugas ke perawat lain, dan ada perawat yang ketakutan (Irwanto \& Moeliono, 2006).

Perawat merupakan bagian penting dalam pelayanan kesehatan dan memegang peranan dalam proses pengobatan, perawatan, dan memberikan dukungan terhadap pasien. Salah satu tugas perawat adalah memberikan asuhan keperawatan dengan melakukan tindakan keperawatan (Republik Indonesia, 2014). Namun, pada kenyataannya stigma perawat masih tinggi kepada ODHA. Sikap stigma yang dilakukan oleh perawat terhadap ODHA seperti tidak mau melakukan perawatan dan melakukan cemooh kepada ODHA disaat melakukan akses kepelayanan kesehatan (Suratini, 2011). Sikap menstigma tersebut disebabkan oleh faktor pendidikan, pelatihan tentang HIV, tempat kerja, religiusitas, agama, dan rumah sakit itu sendiri (Waluyo et al., 2015).

Salah satu faktor yang dapat menyebabkan terjadinya stigma perawat adalah pengetahuan. Semakin rendah pengetahuan tentang HIVIAIDS maka akan semakin berisiko untuk melakukan stigma yang akan membuat ODHA menutup diri terhadap orang lain dan akan sulit untuk mencegah penularan (Sosodoro et al., 2009).

Tujuan dari penelitian ini adalah untuk mengetahui hubungan antara pengetahuan dengan stigma perawat terkait ODHA di salah satu RS swasta di Yogyakarta.

\section{METODE}

Penelitian ini merupakan penelitian kuantitatif dengan desain cross sectional yang bertujuan untuk mengetahui hubungan pengetahuan dengan stigma perawat terkait ODHA di salah satu RS swasta di Yogyakarta pada bulan Desember 2016-Februari 2017. Subjek dalam penelitian ini adalah perawat yang bekerja di bangsal yang kemugkinan menangani pasien ODHA di RS tersebut. Sampel yang digunakan berjumlah 63 orang. Tehnik sampling yang digunakan dengan purposive sampling. Terdapat kriteria inklusi dan eksklusi yang digunakan. Kriteria inklusi yaitu perawat yang bekerja di bangsal yang menangani pasien ODHA, perawat yang telah mendapatkan pelatihan mengenai HIV, dan perawat yang bersedia menjadi responden, sedangkan kriteria ekslusi yaitu perawat yang cuti.

Instrumen dalam penelitian menggunakan kuesioner HIV-KQ-18 untuk mengukur pengetahuan tentang HIV. Kuesioner ini terdiri dari 18 pertanyaan tentang cara penularan, diagnosis, dan pencegahan HIV. Skala yang digunakan dalam kuesioner ini dengan menggunakan skala Guttman. Instrumen HIV-KQ-18 hanya diujikan uji keterbacaan oleh peneliti sebelumnya. Interpretasi pengetahuan baik jika $(x)>$ mean $+1 S D$, pengetahuan sedang jika mean $-1 \mathrm{SD} \leq$ nilai $(\mathrm{x}) \leq$ mean $+1 \mathrm{SD}$, pengetahuan kurang jika $(x)<$ mean - 1 SD (Laila, 2014).

Kuesioner SHASS untuk mengukur sikap stigma perawat terhadap ODHA. Instrumen SHASS sudah dilakukan uji validitas oleh peneliti sebelumnya didapatkan Alpha Cronbach sebesar $>0,7$ yang berarti dapat diterima dan nilai $r$ hitung diatas nilai $r$ tabel $(>0,2)$ (Kustanti, 2015). Interpretasi stigma tinggi jika $X>\mu+t_{\left(\frac{\alpha}{2}, n-1\right)} \frac{s}{\sqrt{n}}$ stigma sedang jika

$\mu-t_{\left(\frac{\alpha}{2}, n-1\right)} \frac{s}{\sqrt{n}} \leq X \leq \mu+t_{\left(\frac{\alpha}{2}, n-1\right)} \frac{s}{\sqrt{n}} \quad$ rendah jika $X<\mu-t_{\left(\frac{\alpha}{2}, n-1\right)} \frac{s}{\sqrt{n}}$ (Azwar, 2016). Analisis yang 
digunakan dalam pengujian hasil dengan uji korelasi Spearman rank yang bertujuan untuk menguji hubungan. ljin etik penelitian diperoleh dari Komisi Etik Fakultas Kedokteran Universitas Gadjah Mada, Yogyakarta.

\section{HASIL}

\section{Karakteristik Responden}

Karakteristik responden dalam penelitian ini (Tabel 1) menunjukkan bahwa sebagian besar responden berusia $>35$ tahun sebanyak 35 responden $(55,6 \%)$, berjenis kelamin perempuan sebanyak $48(76,2 \%)$, beragama
Islam sebanyak 63 responden (100\%), bersuku Jawa sebanyak 63 responden $(100 \%)$, bertempat tinggal di Yogyakarta dan Sleman masing-masing sebanyak 15 respoden $(23,8 \%)$, lama bekerja $>13$ tahun sebanyak 35 responden (55,6\%), pendidikan terakhir D3 sebanyak 49 responden $(77,8 \%)$, pernah melakukan pelatihan tentang HIVIAIDS sebanyak 36 responden $(57,1 \%)$, pernah melakukan pelayanan atau menangani ODHA sebanyak 34 responden (54\%), dan tahu tentang ODHA sebanyak 43 responden $(68.3 \%)$.

Tabel 1. Karakteristik Responden pada Bulan Desember 2016-Februari 2017

\begin{tabular}{clcc}
\hline No & Karakteristik & $\begin{array}{c}\text { Frekuensi } \\
(\mathbf{n}=63)\end{array}$ & $\begin{array}{c}\text { Persentase } \\
(\%)\end{array}$ \\
\hline 1. & Usia (Tahun) & & \\
& $>35$ & 35 & 55,6 \\
& $\leq 35$ & 28 & 44,4 \\
2. & $\begin{array}{l}\text { Jenis Kelamin } \\
\text { Laki-laki }\end{array}$ & 15 & 23,8 \\
& $\begin{array}{l}\text { Perempuan } \\
\text { 3. }\end{array}$ & 48 & 76,2 \\
Agama & Islam & 63 & 100 \\
4. & Suku & & \\
& Jawa & 63 & 100
\end{tabular}

5. Alamat tempat tinggal Yogyakarta $\quad 15$ Sleman $\quad 15$

Bantul

$15 \quad 23,8$

Gunung Kidul

$13 \quad 20,6$

Kulon Progo

Tidak Diisi

1,6

6. Lama Bekerja

(Tahun)

19,1

$>13$

55,6

$\leq 13$

$\begin{array}{ll}35 & 55,6 \\ 28 & 44,4\end{array}$

7. Pendidikan Terakhir

SPK

D3

Sarjana (S1) 


\begin{tabular}{|c|c|c|c|}
\hline No & Karakteristik & $\begin{array}{c}\text { Frekuensi } \\
(n=63)\end{array}$ & $\begin{array}{c}\text { Persentase } \\
(\%)\end{array}$ \\
\hline \multirow[t]{4}{*}{8.} & Pelatihan & & \\
\hline & Pernah & 36 & 57,1 \\
\hline & Belum Pernah & 25 & 39,7 \\
\hline & Tidak Diisi & 2 & 3,2 \\
\hline \multirow[t]{4}{*}{9.} & $\begin{array}{l}\text { Pelayanan ke } \\
\text { ODHA }\end{array}$ & HA atau Mer & langani \\
\hline & Pernah & 34 & 54 \\
\hline & Belum Pernah & 17 & 27 \\
\hline & Tidak Diisi & 12 & 19 \\
\hline \multirow[t]{4}{*}{10.} & Tahu ODHA & & \\
\hline & Tahu & 43 & 68,3 \\
\hline & Tidak Tahu & 5 & 7,9 \\
\hline & Tidak Diisi & 15 & 23,8 \\
\hline
\end{tabular}

Sumber: Data Primer, 2017

\section{Tingkat Pengetahuan}

Pada penelitian ini didapatkan hasil skor Dari data tersebut dapat disimpulkan bahwa pengetahuan perawat (Tabel 2) dengan sebagian besar tingkat pengetahuan perawat rata-rata skor 14.41 dan median 15, standar yang bekerja di bangsal yang menangani deviasi 2,454 , nilai miminal yang didapatkan ODHA mempunyai pengetahuan cukup 8 , dan nilai maksimal yang didapatlan 18 . dengan jumlah 40 responden $(63,5 \%)$.

Tabel 2. Skor Pengetahuan dan Tingkat Pengetahuan Perawat yang Bekerja padaBulan Desember 2016-Februari 2017

\begin{tabular}{|c|c|c|c|c|c|c|c|c|}
\hline & Mean & Median & $\begin{array}{c}\text { Std. } \\
\text { Deviation }\end{array}$ & Minimun & Maximum & $\begin{array}{c}\text { Tingkat } \\
\text { Pengetahuan }\end{array}$ & Frekuensi & $\begin{array}{c}\text { Persen } \\
\text { tase }(\%)\end{array}$ \\
\hline \multirow{4}{*}{$\begin{array}{c}\text { Skor } \\
\text { Pengetahuan }\end{array}$} & \multirow{4}{*}{14,41} & \multirow{4}{*}{15} & \multirow{4}{*}{2,454} & \multirow{4}{*}{8} & \multirow{4}{*}{18} & Baik & 14 & 22,2 \\
\hline & & & & & & Cukup & 40 & 63,5 \\
\hline & & & & & & Kurang & 9 & 14,3 \\
\hline & & & & & & Total & 63 & 100 \\
\hline
\end{tabular}

Sumber: Data Primer Penelitian, 2017

\section{Stigma Perawat Terkait ODHA}

Pada penelitian ini didapatkan hasil skor sikap stigma perawat (Tabel 3) dengan skor rata-rata 104,84, median 106, standar deviasi 7,825 , nilai minimal yang didapatkan 87, dan nilai maksimal yang didapatkan
123. Dari tabel tersebut dapat disimpulkan bahwa sebagian besar stigma perawat terkait ODHA perawat yang bekerja di bangsal yang menangani ODHA di RS tersebut mempunyai stigma tinggi dengan jumlah 50 responden $(79,4 \%)$. 
Tabel 3. Skor Stigma dan Kategori Stigma Perawat Terkait ODHA yang Bekerja

pada Bulan Desember 2016-Februari 2017

\begin{tabular}{|c|c|c|c|c|c|c|c|c|}
\hline & Mean & Median & $\begin{array}{c}\text { Std. } \\
\text { Deviation }\end{array}$ & Minimun & Maximum & $\begin{array}{c}\text { Stigma } \\
\text { Perawat }\end{array}$ & Frekuensi & $\begin{array}{c}\text { Persentase } \\
(\%)\end{array}$ \\
\hline \multirow{3}{*}{ Skor Stigma } & \multirow{3}{*}{104,84} & \multirow{3}{*}{106} & \multirow{3}{*}{7,825} & \multirow{3}{*}{87} & \multirow{3}{*}{123} & Rendah & 10 & 15,9 \\
\hline & & & & & & Sedang & 3 & 4,8 \\
\hline & & & & & & $\begin{array}{l}\text { Tinggi } \\
\text { Total }\end{array}$ & $\begin{array}{l}50 \\
63\end{array}$ & $\begin{array}{l}\frac{79,4}{100} \\
\end{array}$ \\
\hline
\end{tabular}

Sumber: Data Primer Penelitian, 2017

\section{Hubungan Pengetahuan dengan Stigma Perawat terkait ODHA}

Dari hasil analisis tabulasi silang (Tabel 4) didapatkan hasil bahwa sebagian besar perawat dengan pengetahuan cukup mempunyai stigma yang tinggi, yaitu sebanyak 30 responden $(47,6 \%)$. Sebanyak 11 responden $(17,5 \%)$ dengan pengetahuan yang baik mempunyai stigma yang tinggi, dan sebanyak 3 responden $(4,8 \%)$ dengan pengetahuan baik mempunyai stigma yang rendah. Hasil tabel tersebut menunjukkan bahwa tidak terdapat hubungan bermakna $(p$-value $>0,05)$ antara pengetahuan dengan stigma perawat terkait ODHA. Berdasarkan tabel 3 di atas nilai $r$ sebesar 0,070 dengan arah korelasi negatif (semakin tinggi pengetahuan perawat maka stigma perawat terkait ODHA semakin rendah).

Tabel 4. Tabulasi Silang dan Hubungan antara Pengetahuan dengan Stigma Perawat Terkait ODHA pada bulan Desember 2016-Februari 2017

\begin{tabular}{lcccccc}
\hline \multirow{2}{*}{$\begin{array}{c}\text { Tingkat } \\
\text { Pengetahuan } \\
\text { Perawat }\end{array}$} & \multicolumn{3}{c}{ Stigma Perawat } & Total & $\begin{array}{c}\text { Koefisien } \\
\text { Korelasi (r) }\end{array}$ & p-value \\
\cline { 2 - 4 } & Rendah & Sedang & Tinggi & & & \\
\hline Baik & $3(4,8 \%)$ & $0(0 \%)$ & $11(17,5 \%)$ & $14(22,2 \%)$ & & \\
Cukup & $7(11,1 \%)$ & $3(4,8 \%)$ & $30(47,6 \%)$ & $40(63,5 \%)$ & $-0,07$ & 0,588 \\
Kurang & $0(0 \%)$ & $0(0 \%)$ & $9(14,3 \%)$ & $9(14,3 \%)$ & & \\
Total & $10(15,9 \%)$ & $3(4,8 \%)$ & $50(79,4 \%)$ & $63(100 \%)$ & & \\
\hline
\end{tabular}

Sumber: Data Primer Penelitian, 2017

Hasil tabel 5 menunjukkan bahwa nilai rata-rata skor pengetahuan dan skor stigma dengan lama bekerja lebih dari 13 tahun mempunyai nilai rata-rata lebih tinggi dibandingkan dengan kurang dari 13 tahun, nilai rata-rata skor pengetahuan dan skor stigma dengan pendidikan terakhir D3 mempunyai nilai rata-rata lebih tinggi dibandingkan dengan S1 dan SPK, nilai rata-rata skor pengetahuan yang pernah melakukan pelatihan mempunyai nilai ratarata yang lebih tinggi dibandingkan dengan yang belum melakukan pelatihan dan responden yang belum melakukan pelatihan mempunyai stigma lebih tinggi, nilai ratarata skor pengetahuan dan skor stigma yang belum penah melakukan pelayanan ke ODHA atau menangani ODHA mempunyai nilai ratarata lebih tinggi dibandingkan dengan yang penah melakukan pelayanan ke ODHA atau menangani ODHA, dan nilai rata-rata skor pengetahuan yang tahu tentang ODHA lebih tinggi dibandingkan yang tidak tahu dan nilai rata-rata skor stigma yang tidak tahu tentang ODHA lebih tinggi dibandingkan dengan yang tahu tentang ODHA. 
Tabel 5. Nilai Rata-Rata Skor Pengetahuan Perawat dan Stigma Perawat dengan Karakteristik Responden di Salah Satu Rumah Sakit Swasta di Yogyakarta pada bulan Desember 2016-Februari 2017

\begin{tabular}{|c|c|c|c|c|}
\hline \multirow[b]{2}{*}{ No. } & \multirow[b]{2}{*}{ Variabel } & \multicolumn{2}{|c|}{ Mean } & \multirow[b]{2}{*}{$\mathbf{N}$} \\
\hline & & $\begin{array}{c}\text { Skor Pengetahuan } \\
\text { Perawat }\end{array}$ & $\begin{array}{c}\text { Skor Stigma } \\
\text { Perawat }\end{array}$ & \\
\hline \multirow[t]{3}{*}{1.} & Lama Bekerja (Tahun) & & & \\
\hline & $>13$ & 14,57 & 106,26 & 25 \\
\hline & $\leq 13$ & 14,21 & 103,07 & 28 \\
\hline \multirow[t]{5}{*}{2.} & Pendidikan Terakhir & & & \\
\hline & SPK & 12 & 108 & 1 \\
\hline & D3 & 14,47 & 105,76 & 49 \\
\hline & Sarjana (S1) & 14,33 & 101,08 & 12 \\
\hline & Tidak Diisi & 15 & 102 & 1 \\
\hline \multirow[t]{4}{*}{3.} & Pelatihan & & & \\
\hline & Pernah & 15,03 & 102,56 & 36 \\
\hline & Belum Pernah & 13,96 & 107,76 & 25 \\
\hline & Tidak Diisi & 9 & 109,50 & 2 \\
\hline \multirow[t]{5}{*}{4.} & Pelayanan ke ODHA atau Menangani & & & \\
\hline & ODHA & 14,53 & 102,59 & 24 \\
\hline & Pernah & 14,94 & 106,94 & 17 \\
\hline & Belum Pernah & 13,33 & 108,25 & 12 \\
\hline & Tidak Diisi & & & \\
\hline \multirow[t]{4}{*}{5.} & Tahu ODHA & & & \\
\hline & Tahu & 14,65 & 104,14 & 43 \\
\hline & Tidak Tahu & 14 & 104,40 & 5 \\
\hline & Tidak Diisi & 13,87 & 107 & 15 \\
\hline
\end{tabular}

Sumber: Data Primer Penelitian, 2017

\section{DISKUSI}

\section{Tingkat Pengetahuan}

Hasil penelitian ini menunjukkan nilai rata-rata pengetahuan perawat sebesar 14,41 dengan rentang nilai $8-18$. Hasil ini lebih tinggi dibandingkan dengan penelitian yang dilakukan oleh Waluyo et al. (2015) yang memperoleh rata-rata 12,5 dengan rentang nilai 4-18 yang bertempat di Jakarta.

Faktor yang memengaruhi pengetahuan seseorang adalah faktor pengalaman, tingkat pendidikan, keyakinan, fasilitas, penghasilan, dan sosial budaya (Wulandari, 2012). Salah satu faktor yang memengaruhi pengetahuan adalah lama bekerja yang diharapkan semakin lama bekerja maka akan mempunyai pengalaman lebih banyak sehingga pengetahuan yang dimiliki lebih baik (Saragih \& Rumapea, 2015). Jika terdapat pengetahuan yang rendah tentang cara penularan atau pencegahan HIV pada tenaga kesehatan maka akan memberikan perilaku diskriminatif dan sikap stigma kepada ODHA.

Salah satu cara dalam meningkatkan pengetahuan seseorang dengan melakukan pendidikan kesehatan khususnya tentang cara pencegahan penyakit HIVIAIDS (Taher et al., 2013). Dalam melakukan pendidikan kesehatan tersebut dapat menggunakan metode peer education, metode curah pendapat, dan ceramah dengan menggunakan audio visul yang terbukti efektif dalam meningkatkan pengetahuan dan sikap seseorang (Dewi, 2008; Saputra, 2011). Selain itu, dengan memberikan pelatihan tentang pencegahan HIVIAIDS juga dapat meningkatkan pengetahuan seseorang dan memberikan sikap positif saat melakukan perawatan kepada ODHA (USAID, 2007; Okpala et al., 2017). 


\section{Stigma Perawat}

Pada penelitian ini sebagian besar mempunyai stigma tinggi sebanyak 50 responden $(79,4 \%)$. Sesuai dengan penelitian yang dilakukan oleh Waluyo et al. (2015) bahwa stigma perawat Indonesia masih tinggi terkait dengan HIV. Stigma tinggi disebabkan aoleh adanya ketakutan terhadap penularan HIV kepada petugas kesehatan, selain itu salahnya presepsi terhadap penularan dan pencegahan juga berpengaruh terbentuknya diskriminasi kepada ODHA oleh tenaga kesehatan (Harapan et al., 2013; Wulandari, 2012).

Kesalahpahaman akan penularan atau transmisi tentang HIVIAIDS menjadi penyebab utama terjadinya sikap stigma dan diskriminasi yang dilakukan oleh tenaga kesehatan. Stigma yang dilakukan oleh tenaga kesehatan akan menjadi penghalang atau hambatan saat ODHA melakukan pengobatan sehingga proses pengobatan tersebut tidak efektif (Varas-Diaz et al., 2016).

Kebutuhan yang dapat digunakan dalam mencegah hal tersebut dengan memperkuat informasi, pendidikan, dan komunikasi dari upaya pencegahan HIVIAIDS serta hukum ditegakkan dengan jelas supaya sikap stigma dan diskriminasi dapat dicegah (Ullah, 2011). Untuk menurunkan sikap stigma dan diskriminasi yang terjadi kepada ODHA yang dapat dilakukan oleh perawat dengan menunjukkan kasih sayang dan membuat penyesuaian perawatan kepada ODHA dalam menurunkan manifestasi yang terjadi, serta melakukan tindakan pencegahan seperti melindungi kerahasiaan pasien (Mill et al., 2013).

Diskriminasi dapat dihindari jika perawat tidak mempunyai ketakutan untuk tertular. Faktor tersebut yang memengaruhi perawat melakukan diskriminasi kepada ODHA. Cara yang dapat digunakan dalam mengatasi hal tersebut dengan memberikan pelatihan tentang HIVIAIDS dan perawat memakai alat pelindung diri saat melakukan intervensi kepada ODHA (Okpala et al., 2017). Pelatihan merupakan salah satu strategi yang direkomendasikan dalam mengurangi stigma yang terjadi kepada ODHA oleh dokter dan perawat (Andrewin \& Chien, 2008). Selain itu, dalam meminimalkan terjadinya sikap stigma dan diskriminasi perlu adanya peningkatan pendidikan oleh tenaga kesehatan yang akan menghasilkan ilmu yang lebih baik mengenai HIVIAIDS dan peran dari intansi juga penting dalam meminimalkan hal tersebut (Famoroti et al., 2013).

Pelatihan yang dapat digunakan dalam menurunkan stigma pada tenaga kesehatan dengan pelatihan SPACE intervention. Bentuk intervensi tersebut dengan memberikan workshop tentang sumber dan fungsi stigma dari teori Goffman dan social cognitive theory yang mendasari perubahan sikap dan perilaku seseorang. Selain itu, diberikannya informasi yang faktual tentang HIV/AIDS, mendorong pemikiran kritis tentang peran emosi dalam stigma sosial, keterampilan dalam berinteraksi dengan ODHA yang tidak menyebabkan stigma, dan meningkatkan kesadaran tentang keadaan sosial yang menyebabkan stigma sehingga akan memberikan pelayanan yang bebas dari stigma. Pada bagian emosi, para peserta pelatihan diberikan informasi tentang peran emosi negatif (takut, malu, jijik, dan lain-lain) yang berpengaruh terhadap mempercepat sikap dan perilaku stigma yang kemudian peserta diberikan kasus dan peserta menjelaskan emosi yang mereka alami. Terjadinya peningkatan emosi positif saat interaksi sosial dan pelayanan kesehatan terhadap ODHA memberikan hasil yang signifikan dalam menurunkan stigma (VarasDiaz et al., 2016).

Selain pelatihan, dapat juga dengan melakukan permainan dengan pendekatan 
pengalaman yang mampu secara efektif untuk menurunkan stigma terkait HIV. Di dalam kegitan tersebut, peserta melakukan diskusi kelompok bersama ODHA yang akan menghasilkan rasa empati. Rasa empati didapatkan dari hal yang diceritakan oleh ODHA, kemudian peserta bermain peran menjadi ODHA dan harus memilih tindakan seperti apa yang harus dilakukan. Pada akhir diskusi peserta diminta untuk menjelaskan alasan dalam memilih keputusan yang diambil, perasaan, dan hal yang dipikirkan selama permainan. Rasa empati tersebut merupakan peran penting dalam penurunan stigma yang dilakukan oleh tenaga kesehatan (Mak et al., 2015).

\section{Hubungan Pengetahuan dengan Stigma Perawat Terkait ODHA}

Dari hasil penelitian didapatkan bahwa tidak terdapat hubungan bermakna $(p$-value $>0,05)$ antara pengetahuan dengan stigma perawat terkait ODHA di salah satu rumah sakit di Yogyakarta. Pengetahuan tentang HIV bukan merupakan salah satu prediktor yang signifikan dari sikap stigma (Waluyo et al., 2015). Jika dilihat dari tabel 4, tidak ada hubungan dapat karena selisih nilai rata-rata skor pengetahuan dari setiap karakteristik tidak terlalu jauh dan dapat dilihat bahwa keseluruhan niai rata-rata skor stigma berada pada kategori stigma tinggi. Beberapa kemungkinan penyebabnya, yaitu sampel yang tidak representatif (distribusi yang tidak normal dan ukuran sampel yang terlalu kecil), instrumen tidak valid dan reliabel, tidak dikendalikan variabel luaran/variabel random (tidak memperhitungkan adanya variabel tersebut yang berpengaruh terhadap sampel yang diteliti), desain penelitian yang tidak tepat, dan metode analisis yang tidak sesuai (Nursalam, 2003). Pada penelitian ini tidak dikendalikan variabel luaran/variabel random.
Dari hasil tabulasi silang (Tabel 4) dapat dilihat bahwa sebagian besar perawat dengan pengetahuan cukup mempunyai stigma yang tinggi sebanyak 30 responden (47.6\%). Sehingga diperlukan suatu cara untuk meningkatkan pengetahuan dan menurunkan stigma perawat terkait ODHA karena salah satu kendala dalam pengendalian pecegahan penularan HIVIAIDS adalah adanya stigma dan diskriminasi terkait ODHA.

Cara yang dapat digunakan dengan melakukan pelatihan tentang pencegahan infeksi HIVIAIDS, saat melakukan intervensi kepada ODHA perawat menggunakan alat pelindung (sarung tangan, pelindung kepala, kacamata, masker, gaun, sepatu, dan lainlain) yang disesuaikan dengan tindakan yang dilakukan, memberikan informasi yang jelas dan akurat mengenai HIVIAIDS (khususnya tentang cara penularan), adanya kurikulum tentang cara merawat ODHA saat menjadi mahasiswa keperawatan, memberikan pelatihan dengan SPACE intervention atau program Train The Trainer kepada tenaga kesehatan, dan kebijakan yang jelas dari pemerintah (Badahdah, 2010; Famoroti, Fernandes, \& Chima, 2013; Nyamathi et al., 2008; Okpala et al., 2017; Shah et al., 2014; USAID, 2007; Varas-Diaz et al., 2016; Zarai et al., 2015).

Selain itu, diberikannya kuliah atau workshop dari seorang ahli dan ODHA akan memberikan efek yang mendalam pada siswa saat masih menjadi mahasiswa keperawatan, sehingga dapat mengurangi stigma dan mengurangi kekhawatiran saat merawat ODHA setelah lulus (Frain, 2017).

Pendidikan kesehatan tentang HIVIAIDS terbukti dapat meningkatkan pengetahuan perawat tentang cara penularan, perlindungan diri atau universal precaution, dan informed consent. Ketiga hal tersebut sangat membantu jika diberikan secara informatif dan sesuai dengan kebutuhan perawat. Selain itu, 
dampak diberikannya pendidikan kesehatan juga berpengaruh terhadap penurunan sikap stigma seperti ketakutan perawat terhadap pasien HIV dan penularan HIV (Pisal et al., 2007).

\section{SIMPULAN}

Tingkat pengetahuan perawat berada pada kategori cukup, stigma perawat terkait ODHA pada kategori tinggi, dan tidak terdapat hubungan antara pengetahuan dengan stigma perawat terkait ODHA di salah satu RS swasta di Yogyakarta.

Bagi institusi pendidikan dapat menambahkan kurikulum stigma perawat terkait ODHA, melakukan kuliah atau workshop dengan ahli, ODHA, Dinas Kesehatan, dan pelayanan kesehatan, dan pelatihan tentang HIVIAIDS. Sehingga, setelah lulus dari sekolah keperawatan mampu mengatasi kecemasan dan meminimalisir melakukan stigma kepada ODHA. Bagi institusi pelayanan kesehatan dapat melakukan pelatihan dengan SPACE intervention atau Train the Trainer kepada tenaga kesehatan tetang HIVIAIDS, diskusi langsung dengan ODHA, dan menyediakan universal precaution bagi tenaga kesehatan yang memberikan intervensi kepada ODHA. Bagi pemerintah dapat mempertegas kebijakan mengenai stigma kepada ODHA, memberikan informasi yang faktual kepada masyarakat maupun tenaga kesehatan tentang penularan dan pencegahan HIVIAIDS, dan melakukan penyuluhan kepada masyarakat tentang penularan dan pencegahan HIVIAIDS. Bagi peneliti selanjutnya dapat meneliti lebih lanjut tentang faktor-faktor yang mempengaruhi pengetahuan dan stigma pada mahasiswa keperawatan dan perawat.

\section{UCAPAN TERIMA KASIH}

Peneliti mengucapkan terima kasih kepada pihak-pihak yang telah mendukung proses penelitian. Terima kasih kepada direktur intansi terkait dan jajarannya, diklat intansi terkait dan jajarannya, perawat yang telah bersedia menjadi responden, dan Bapak Agung Waluyo yang telah memberikan izin dalam penggunaan kuesioner HIV-KQ-18.

\section{DAFTAR PUSTAKA}

Andrewin, A., \& Chien, L.-Y. (2008). Stigmatization of patients with HIVIAIDS among doctors and nurses in Belize. AIDS Patient Care and STDs, 22(11): 897-906.

Azwar, A. (2016). Penyusunan skala psikologi (Edisi 2). Yogyakarta: Pustaka Pelajar.

Badahdah, A. M. (2010). Stigmatization of persons with HIVIAIDS in Saudi Arabia. Journal of Transcultural Nursing, 2(4): 386-392.

Dewi, N. S. Pengaruh pendidikan kesehatan terhadap perubahan pengetahuan dan sikap dalam pencegahan HIVIAIDS pada pekerja seks komersial. Media Ners, 2(1): 15-22.

Chandra, A. S., Sugiarto, C., \& Jonathan, R. (2013). Gambaran penularan dan stigma pada perempuan dengan Human Immunodeficiency Virus/Acquired Immune Deficiency Syndrome di klinik swasta khusus Kota Bandung. Retrieved from http://repository.maranatha. edu/12102/9/1010023_Journal.pdf

Famoroti, T. O., Fernandes, L., \& Chima, S. C. (2013). Stigmatization of people living with HIVIAIDS by health care workers at a tertiary hospital in KwaZuluNatal, South Africa: A cross-sectional descriptive study. BMC Medical Ethics: 1-10.

Frain, J. A. (2017). Preparing every nurse to become an HIV nurse. Nurse Education Today, 48: 129-133.

Harapan, H., Feramuhawan, S., Kurniawan, H., Anwar, S., Andalas, M., \& Hossain, M. B. (2013). HIV-realted stigma and 
discrimination: A study of health care workers in Banda Aceh, Indonesia. Med $J$ Indones, 22(1): 22-29.

Irwanto \& Moeliono, L. (2006). ODHA dan akses pelayanan kesehatan dasar penelitian partisipatif. Jakarta: Komisi Penanggulangan AIDS. Retrieved from http://spiritia.or.id/dokumen/odha-akses. pdf

Kemekes RI. (2014). INFODANTIN pusat data dan informasi Kementrian Kesehatan RI: Situasi dan analisis HIV AIDS. Jakarta: Kementrian Kesehatan RI. Retrieved from http://www.depkes. go.id/resources/download/pusdatin/ infodatin/Infodatin\%20AIDS.pdf

Kemenkes RI. (2013). Peraturan Mentri Kesehatan RI tentang penanggulangan HIV AIDS nomor 21 Tahun 2013. Retrieved from http://pppl.depkes.go.id/ asset/_regulasi/100_Permenkes $\% 20$ No\%2021\%20Tahun \%202013\%20 Penanggulangan\%20HIVAIDS.pdf

Kemenkes RI Ditjen PP dan PL. (2012). Buku pedoman penghapusan stigma dan diskriminasi bagi pengelola program, petugas layanan kesehatan, dan kader. Jakarta: Kementrian Kesehatan RI.

Kemenkes RI Ditjen PP dan PL. (2014). Statistik kasus HIVIAIDS di Indonesia dilapor s/d september 2014. Retrieved from http://spiritia.or.id/Stats/StatCurr. pdf

Kemenkes RI Ditjen PP dan PL. (2015). Laporan perkembangan HIV-AIDS triwulan III tahun 2015. Jakarta: Kementrian Kesehatan RI. Retrieved from http://aidsindonesia.or.id/ck uploads/files/FINAL_LAPORAN\%20 PERKEMBANGAN \% 20 HIV $\% 20$ AIDS\%20TRIWULAN\%20III\%202015. pdf

Komisi Penanggulangan AIDS Provinsi DIY. (2016). Data kasus HIV dan AIDS DIY sampai dengan Maret 2016. Retrieved from: http://aidsyogya.or.id/2016/datahiv-aids/data-kasus-hiv-aids-diy-sdmaret-2016/

Kustanti, A. (2015). Pengaruh workshop mengenal HIV/AIDS terhadap stigma terkait HIV dan AIDS pada mahasiswa Program Studi IImu Keperawatan Fakultas Kedokteran Universitas Gadjah Mada. (Tesis). Universitas Gadjah Mada, Yogyakarta, Indonesia.

Laila, A. (2014). Tingkat pengetahuan remaja tentang HIVIAIDS pada siswa kelas $X$ di SMA Warga Kota Surakarta. (Karya Tulis IImiah). Sekolah Tinggi IImu Kesehatan Kusuma Husada Surakarta, Jawa Tengah, Indonesia.

Mak, W. W., Cheng, S. S., Law, R. W., Cheng, W. W., \& Chan, F. (2015). Reducing HIV-related stigma among healthcare professionals: A game-based experiential approach. AIDS Care, 27(7): 855-859.

Mill, J., Harrowing, J., Rae, T., Richter, S., Minnie, K., Mbalinda, S., \& HepburnBrowwn, C. (2013). Stigma in AIDS nursing care in Sub-Saharan Africa and the Caribbean. Qualitative Health Research, 13(8): 1066-1078.

Nursalam. (2003). Konsep dan penerapan metodologi penelitian ilmu keperawatan: Pedoman skripsi, tesis, dan instrumen penelitian keperawatan (edisi pertama). Jakarta: Salemba Medika.

Nyamathi, A., Vatsa, M., Khakha, D. C., McNeese-Smith, D., Leake, B., \& Fahey, J. L. (2008). HIV knowledge improvement among nurses in India: Using a train-the-trainer program. Journal of The Association of Nurses in AIDS Care, 19(6): 443-449.

Okpala, P. U., Uwak, R., Nwaneri, A. C., Onyiapat, J.-I., Emesowum, A., Osuala, E. O., \&Adeyemo, F. O. (2017, February). 
Nurses' knowledge and attitude to the care of HIVIAIDS patients in South East, Nigeria. International Journal of Community Medicine and Public Health, 4(2): 547-553.

Pisal, H., Sutar, S., Sastry, J., KapadiaKundu, N., Joshi, A., Joshi, M., . . . Shankar, A. V. (2007). Nurses' health education program in India increases HIV knowledge and reduces fear. Journal of The Association of Nurses in AIDS Care, 18(6): 32-43.

Republik Indonesia. (2014). UU RI nomor 38 tahun 2014 tentang keperawatan. Retrieved from http://kemenkopmk. go.id/sites/default/files/produkhukum// UU\%20Nomor\%2038\%20Tahun $\% 20$ 2014.pdf

Saputra, N. (2011). Perbedaan pengaruh pendidikan kesehatan HIV AIDS dengan metode curah pendapat dan ceramah menggunakan media audio visual terhadap pengetahuan siswa SMAN 4 Tangerang Selatan. Retrieved from http://repository.uinjkt.ac.id/ dspace/bitstream/123456789/1300/1/ NAZARWIN\%20SAPUTRA-FKIK.PDF

Saragih, R., \& Rumapea, N. (2011). Hubungan karakteristik dengan tingkat kepatuhan perawat melakukan cuci tangan di Rumah Sakit Columbia Asia Medan. Retrieved from http://www.academia. edu/6607236/Hubungan_Karakteristik_ Perawat_Dengan_Tingkat_Kepatuhan_ Perawat

Shah, S. M., Heylen, E., Srinivasan, K., Perumpil, S., \& Ekstrand, M. L. (2014). Reducting HIV stigma among nursing students: A brief intervention. Western Journal of Nursing Research, 36(10): 1323-1337.

Sosodoro, O., Emilia, O., \& Wahyuni, B. (2009). Hubungan pengetahuan tentang HIVIAIDS dengan stigma orang dengan
HIVIAIDS di kalangan pelajar SMA. Berita Kedokteran Masyarakat: 210-217. Suratini. (2011). Pengalaman orang dengan HIVIAIDS (ODHA) mendapatkan perawatan keluarga di wilayah Kabupaten Kulon Progo Daerah Istimewa Yogyakarta: Studi fenomenologi (Tesis). Universitas Indonesia, Jakarta, Indonesia.

Taher, B. F., Ticoalu, S. H., \& Onibala, F. (2013). Pengaruh pendidikan kesehatan terhadap tingkat pengetahuan siswa tentang cara pencegahan penyakit HIV/ AIDS di SMA Negeri 1 Manado. Ejournal Keperawatan (e-Kp), 1(1): 1-7.

Ullah, A. A. (2011). HIVIAIDS-related stigma and discrimination: A study of health care providers in Bangladesh. Journal of The International Association of Physicians in AIDS Care, 10(2): 97-104.

UNAIDS. (2016). Fact sheet 2016. UNAIDS. Retrieved from http://www.unaids. org/sites/default/files/media_asset/ UNAIDS_FactSheet_en.pdf

USAID. (2007). Evaluation of knowledge, attitudes, and practice of health care providers toward HIV-positive patients in Tanzania. Tanzania: USAID from The American People. Retrieved from http://www.urc-chs.com/sites/default/ files/Evaluation_HealthCareProviders_ Tanzania.pdf.

Varas-Diaz, N., Neilands, T. B., RodriguezMadera, S. L., \& Padilla, M. (2016). The role of emotions in the reduction of HIVIAIDS stigma among physicians in training. AIDS Care, 28(3): 376-383.

Waluyo, A., Culbert, G. J., Levy, J., \& Norr, K. F. (2015). Understanding HIV-related stigma among Indonesian nurses. JANAC, 26(1): 69-80.

Wulandari, F. (2012). Hubungan tingkat pengetahuan perawat tentang perawatan paliatif dengan sikap 
terhadap penatalaksanaan pasien dalam perawatan paliatif di $R S D r$. Moewardi surakarta. Retrieved from http://eprints.ums.ac.id/21972/12/ NASKAH_PUBLIKASI.pdf

Zarai, N., Joulaei, H., Darabi, E., \& Fararouei, M. (2015). Stigmatized attitude of healthcare providers: A barrier for delivering health services to HIV positive patients. IJCBNM, 3(4): 292-300. 